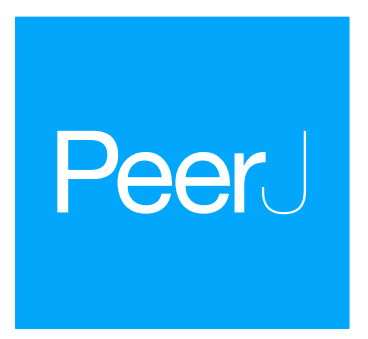

Submitted 24 February 2018

Accepted 2 July 2018

Published 2 August 2018

Corresponding author

Łukasz Jermacz,

lukasjermacz@gmail.com

Academic editor

Richard Taylor

Additional Information and Declarations can be found on page 15

DOI 10.7717/peerj.5311

Copyright

2018 Jermacz and Kobak

Distributed under

Creative Commons CC-BY 4.0

OPEN ACCESS

\section{The Braveheart amphipod: a review of responses of invasive Dikerogammarus villosus to predation signals}

\author{
Łukasz Jermacz and Jarosław Kobak \\ Department of Invertebrate Zoology, Faculty of Biology and Environmental Protection, Nicolaus Copernicus \\ University, Torun, Poland \\ These authors contributed equally to this work.
}

\section{ABSTRACT}

Predator pressure is a fundamental force driving changes at all levels of the community structure. It may protect native ecosystems from alien species. Therefore, resistance to diverse predators resulting from a universal anti-predator strategy seems crucial for invasion success. We present a comprehensive review of the responses of an invasive amphipod Dikerogammarus villosus to sympatric and allopatric predator signals. We summarize diverse aspects of the gammarid anti-predator strategy, including predator identification, morphological and behavioural adaptations, effectiveness of shelter use and resistance to indirect predator effects. The response of $D$. villosus is independent of predator species (including totally allopatric taxa), which assures the high flexibility of its predator recognition system. It has a harder exoskeleton and better capability of utilizing shelters compared to other gammarids, resulting in relatively high resistance to predators. Therefore, it can use predator kairomones as indirect food signals (sharing the diet with the predator) and follow the predator scent. This resistance may allow D. villosus to reduce the costs of its physiological responses to predators and sustain growth in their presence. This might facilitate invasion success by increasing its competitive advantage.

Subjects Animal Behavior, Biodiversity, Ecology, Zoology, Freshwater Biology

Keywords Predator consumptive and non-consumptive effects, Prey-predator interaction, Invasive species, Anti-predator strategy, Kairomones

\section{INTRODUCTION}

Dikerogammarus villosus (Sovinsky, 1894) is a gammarid of Ponto-Caspian origin, commonly regarded as one of the most invasive freshwater species in the world (DAISIE, 2009). In its native region, it lives in the lower courses of large rivers of the Black, Azov and Caspian Sea basins, and in limans formed at their outlets (Rewicz et al., 2014). It has spread in central and western Europe using the southern migration corridor through the Danube and Rhine rivers (Bij de Vaate et al., 2002), as well as the central corridor, through the Dnieper, Bug, Vistula and Elbe rivers (Grabowski, Bacela \& Konopacka, 2007; Mastitsky \& Makarevich, 2007). At present, it occupies the widest novel range (most of Europe, excluding the Iberian and Scandinavian Peninsulas, but including Great Britain) and reaches the highest abundances in invaded areas within the group of several invasive 
Ponto-Caspian gammarid species (Rewicz et al., 2014; Rewicz et al., 2017; Šidagyte et al., 2017; Gusev, Guseva \& Sudnik, 2017).

In novel areas, $D$. villosus exerts a strong impact on local biota through several mechanisms (Gergs \& Rothhaupt, 2015). Firstly, it is an omnivore with a tendency to animal food, efficiently preying on many invertebrate species (Krisp \& Maier, 2005), including intra-guild predation on local amphipod species (Dick \& Platvoet, 2000; MacNeil \& Platvoet, 2005; Kinzler et al., 2009). D. villosus strongly prefers animal food over plants (Van Riel et al., 2006; Gergs \& Rothhaupt, 2008b) and grows better on it (Gergs $\&$ Rothhaupt, 2008a). However, recent field studies have revealed that it can also act as a typical herbivore, consuming mainly plant food (Maazouzi et al., 2009; Hellmann et al., 2015; Koester, Bayer \& Gergs, 2016). This points to its high plasticity and ability to use various available food resources (Mayer, Maas \& Waloszek, 2012), depending on local circumstances, such as the community composition (Hellmann et al., 2017). Moreover, it efficiently competes with other gammarids, both native and other aliens, for food, shelters and optimum habitats (Dick, Platvoet \& Kelly, 2002; Hesselschwerdt, Necker \& Wantzen, 2008; Jermacz et al., 2015a). Competitive tensions and intra-guild predation are responsible for the reduction in the occupied ranges and abundances of native species, which are being outcompeted to less suitable habitats and sometimes even locally displaced (Dick, Platvoet \& Kelly, 2002; Muskó et al., 2007; Hesselschwerdt, Necker \& Wantzen, 2008; Platvoet et al., 2009). Furthermore, D. villosus can exert some more subtle effects on ecosystem functioning. For instance, being a less efficient shredder than other amphipods, displaced by its appearance, $D$. villosus may negatively affect food webs by reducing the numbers of organisms relying on shredded organic material (MacNeil et al., 2011). On the other hand, D. villosus does not respond to predation risk by reduction in feeding (Jermacz $\&$ Kobak, 2017); therefore, it can still be capable of shredding organic material when other amphipods suffer non-consumptive costs of predator pressure (Abjörnsson et al., 2000; Jermacz \& Kobak, 2017; Richter et al., 2018).

The invasion success of $D$. villosus is regarded to result from several traits of its biology, including its fast growth rate, high fecundity, tolerance to wide ranges of abiotic factors, in particular raised salinity (Devin \& Beisel, 2007), as well as high plasticity and omnivory (as reviewed by Grabowski, Bacela \& Konopacka, 2007). Another trait contributing to its spread is the ability to adhere to various hard substrata and artificial materials, including boat hulls and diving equipment (Bacela-Spychalska et al., 2013). Although D. villosus is not well adapted to air exposure (Poznańska et al., 2013), under suitable conditions, e.g., hidden in a zebra mussel colony, individuals of this species can survive several days without water (Martens \& Grabow, 2008), sufficient for successful transport to another water body.

Yet another important trait which can potentially affect the invasive potential of the species is an effective strategy of energy saving (Becker et al., 2016) observed also under predation risk (Jermacz et al., 2017; Jermacz \& Kobak, 2017). In recent years, we have conducted a series of experimental studies on the reactions of D. villosus to predation cues and their potential implications for its functioning and invasiveness. In this review, we provide a synthesis of our research on these topics accompanied by the results of other authors on the biology of $D$. villosus and related amphipod species. 


\section{Survey methodology}

To obtain a comprehensive set of literature reports on interactions between predators and amphipod prey, we conducted a literature survey in the Scopus database, using the following keywords: $D$. villosus or gammarid or amphipod combined with the following: anti-predator response or predator impact or anti-predator behaviour or predator defence or predator kairomone or predation risk or prey response. We found 67, 115 and 927 articles, respectively, meeting the criteria, 11 of which were of our own authorship. Among these articles were chosen key papers related to defence strategies exhibited by native and invasive amphipods.

\section{Prey-predator relationships in the context of biological invasions}

Predation is one of the most powerful forces in nature, affecting the evolution of prey and predator species and modifying interactions among organisms (Mowles, Rundle \& Cotton, 2011; Turner \& Peacor, 2012). On the one hand, predators kill and consume prey individuals, removing them from the population and creating selective pressure, which results in so called "consumptive effects" of a predator (Werner \& Peacor, 2003). On the other hand, prey species respond to the presence of predators by various forms of constitutive (permanent) and induced defences, stimulated by the presence of a predator. These defence mechanisms include behavioural (De Meester et al., 1999; Gliwicz, 2005), morphological (Pettersson, Nilsson \& Brönmark, 2000; Dzialowski et al., 2003; James \& McClintock, 2017), physiological (Slos \& Stoks, 2008; Glazier et al., 2011) and life-history related (Ślusarczyk, Dawidowicz \& Rygielska, 2005) changes aiming at reducing the probability and/or efficiency of a predator attack. Defence responses are displayed by a wide range of taxa, from protozoans (Wiackowski, Fyda \& Ciecko, 2004) through virtually all invertebrate taxa (Koperski, 1997; Lass \& Spaak, 2003; Thoms et al., 2007; Kobak, Kakareko \& Poznańska, 2010) to vertebrates (Gliwicz, 2005). Anti-predation mechanisms can be quite costly, consuming energy designated for the construction of defensive structures and compromising the habitat quality and/or food abundance, which finally leads to the decrease in growth rate and reproduction (Gliwicz, 1994; Gliwicz, 2005; De Meester et al., 1999; Clinchy, Sheriff \& Zanette, 2013). These energetic expenses are called "non-consumptive effects" of predator presence (Werner \& Peacor, 2003) and sometimes generate losses comparable to those caused by consumptive predator effects (Preisser, Bolnick \& Benard, 2005; Creel \& Christianson, 2008). Therefore, the ability to adequately recognize the danger imposed by predators, depending on their feeding mode (Wudkevich et al., 1997; Wooster, 1998; Abjörnsson et al., 2000), present condition (e.g., satiation level) (Abjörnsson et al., 1997), abundance (Pennuto \& Keppler, 2008) and size (Kobak, Kakareko \& Poznańska, 2010) is crucial for avoiding unnecessary (leading to energy wasting) or maladaptive (increasing the probability of death) responses.

Biological invasions add a new and interesting aspect to predator-prey interactions. In old systems, where predator and prey coevolve together for a long time, both are well adjusted to each other. The responses of prey species can be fine-tuned to specific predators (Wudkevich et al., 1997; Weber, 2003; Boeing, Ramcharan \& Riessen, 2006), but also predator preying modes allow them to feed efficiently on available victims 
(Gliwicz, 2005). However, alien species, just transported to their novel locations, face completely new, unknown communities, containing new predators and new prey. In accordance with the Enemy Release Hypothesis (Torchin et al., 2003), as a consequence of the loss of natural parasites and predators, introduced species suffer lower pressure than native species. At the same time, local consumers may be unfamiliar with alien prey and unable to forage on them efficiently (Meijer et al., 2016). On the other hand, alien species are also not adapted to their new, potential predators which may prevent them from employing efficient anti-predation mechanisms and lead to an evolutionary trap: inefficient or even maladaptive responses or the lack of reactions to a danger (Salo et al., 2007; Zuharah \& Lester, 2010).

Recognition of a predator may be based on variable stimuli, including chemical, visual and/or mechanical cues. In the aquatic environment, due to its relative darkness and high density of the medium, chemical recognition is regarded as the most important (Brönmark \& Hansson, 2000). This general rule also applies to gammarids detecting their predators (Wisenden et al., 2009; Hesselschwerdt et al., 2009; Jermacz, DzierżyńskaBiałonczyk \& Kobak, 2017). Prey organisms can potentially recognize three sources of chemical predation cues: alarm cues produced by wounded conspecifics (Czarnołeski et al., 2010; Kobak \& Ryńska, 2014; Jermacz, Dzierżyńska-Białończyk \& Kobak, 2017), scents of consumed conspecifics included in predator faeces (Ślusarczyk \& Rygielska, 2004; Jermacz, Dzierżyńska-Białończyk \& Kobak, 2017) or other exudates and/or direct predator metabolites, independent of their diet (Kobak, Kakareko \& Poznańska, 2010; Jermacz, Dzierżyńska-Białończyk \& Kobak, 2017). The first two options can be potentially utilized by alien organisms to detect unknown predators. Moreover, alien organisms can recognize predators taxonomically related to those living in their native range (Sih et al., 2010) or use learning to associate new predator scents with the perceived danger cues (Chivers, Wisenden \& Smith, 1996; Wisenden, Chivers \& Smith, 1997; Martin, 2014). The latter approach is commonly exhibited by fish (Korpi \& Wisenden, 2001), whereas in invertebrates predator recognition is often innate, displayed also by naïve individuals (Dalesman, Rundle \& Cotton, 2007; Ueshima \& Yusa, 2015).

\section{Predator recognition by $D$. villosus}

For a perfect invasive species, the mechanism of predator detection should be universal, enabling the recognition and subsequent response to a novel predator without a common evolutionary history. As a consequence of an improper identification of a predator signal, prey species are exposed to higher predation due to the lack of responses or maladaptive responses (Abjörnsson, Hansson \& Brönmark, 2004; Banks \& Dickman, 2007). Such a scenario was presented by Pennuto \& Keppler (2008) who demonstrated that a native Gammarus fasciatus is able to avoid a narrower range of potential predators than an invasive Echinogammarus ischnus. Moreover, ineffective recognition of danger could result in costly defence reactions when the predation risk is low (Lima \& Dill, 1990; Dunn, Dick \& Hatcher, 2008) as was experimentally shown for Gammarus minus responding to a predatory fish Luxilus chrysocephalus (Wooster, 1998). Therefore, appropriate predation risk assessment is crucial for an adequate response and optimization of energy expenditure. 
Laboratory experiments demonstrated the ability of $D$. villosus to recognize diverse fish predators, including bottom dwellers: the racer goby Babka gymnotrachelus (Jermacz et al., 2017; Jermacz, Dzierżyńska-Białończyk \& Kobak, 2017), European bullhead Cottus gobio (Sornom et al., 2012) and spiny-cheek crayfish Orconectes limosus (Hesselschwerdt et al., 2009), as well as fish swimming in the water column: the Eurasian perch Perca fluviatilis, Amur sleeper Perccottus glenii (Ł Jermacz \& J Kobak, pers. obs., 2015-2016) and red-bellied piranha Pygocentrus nattereri (Jermacz, Dzierżyńska-Białończyk \& Kobak, 2017). Among these species, the goby, bullhead and perch have co-occurred with the gammarid in its home range, the Amur sleeper and crayfish were met several dozen years ago in its novel areas, whereas the piranha had no previous contact with $D$. villosus. The above-mentioned studies indicate a universal method of predator recognition exhibited by $D$. villosus, effective with regard to both native and novel predatory species. A situation when potential naïve prey recognizes and responds to a novel predator can be explained by several mechanisms. For example, conspecifics can be present in the predator diet, providing information about predation risk (Chivers \& Smith, 1998), as was demonstrated for another invasive gammarid Pontogammarus robustoides (Jermacz, Dzierżyńska-Białończyk \& Kobak, 2017). Moreover, the novel predator can be closely related to some native predators (Ferrari et al., 2007; Sih et al., 2010) and therefore release similar signals.

The avoidance reactions of D. villosus were studied by Jermacz, Dzierżyńska-Białończyk $\&$ Kobak (2017) in a flow-through Y-maze allowing gammarids to select an arm with or without the scent of predators fed on different diets. This study indicated that the avoidance of predators was induced in the presence of kairomones emitted by hungry predators (starving for 3 days), including totally allopatric, tropical P. nattereri (Jermacz, Dzierżyńska-Białończyk \& Kobak, 2017). The avoidance response of D. villosus to another hungry predator, American spiny-cheek crayfish, was noted by Hesselschwerdt et al. (2009). Thus, the predator identification system of $D$. villosus seems to be independent of the presence of conspecifics in the predator's diet. Nevertheless, it should be noted that D. villosus did also recognize the predator diet and used it as an additional source of information about the predator status and current level of predation risk, though its responses to satiated predators did not include avoidance (see the chapter "Positive response of D. villosus to the predation cue” below) (Jermacz, Dzierżyńska-Białończyk \& Kobak, 2017). Avoidance of a hungry predator, which is most determined to obtain food, and modifications of the responses to satiated predators suggest that $D$. villosus is capable of effective risk assessment and flexible responses, adjusted to the current situation. A similar relationship between the level of predator satiation and prey response was observed in the case of a water beetle Acilius sulcatus, responding only to hungry perch, but not to satiated fish (Abjörnsson et al., 1997).

The versatility of the predator detection mechanism of D. villosus could be related to the fact that active components of kairomones emitted by unrelated predators are often very similar (Von Elert \& Pohnert, 2000). Therefore prey can react to diverse predators, including those which evolved in isolated ecosystems. In temperate European water bodies, fish usually have broad diet ranges and most of them feed on invertebrate food at least at particular life stages (Wootton, 1990; Gerking, 1994). Thus, a general response to hungry fish 
of particular size seems beneficial under such conditions. D. villosus is an invasive species characterized by a high dispersal rate. During the dispersal, the probability of meeting a novel predator is high, therefore species exhibiting universal defence mechanisms and/or the capability of quick adaptations are more likely to be successful invaders.

\section{Anti-predator defence mechanisms of $D$. villosus Site selection and shelter occupancy}

For a benthic organism, one of the most important elements of the anti-predator strategy is related to the optimal substratum choice. In general, prey survival rate increases with the level of substratum complexity and heterogeneity (Crowder \& Cooper, 1982; Holomuzki $\&$ Hoyle, 1988; Czarnecka, 2016). Therefore, the distribution of benthic invertebrates depends on the bottom character (Czarnecka et al., 2009; Jermacz et al., 2015b) and their efficiency in using available substrata as shelters (Holomuzki \& Hoyle, 1988; Kobak, Jermacz \& Płachocki, 2014; Kobak et al., 2016).

Compared to other gammarids, D. villosus is regarded as a sit-and-wait animal, spending most of its time in a shelter (Kinzler \& Maier, 2006; Kley et al., 2009; Platvoet et al., 2009; Beggel et al., 2016). It prefers the substratum consisting of large gravel or stones $(>6 \mathrm{~cm}$ in diameter), which provides it with suitable protection and enough empty space to move (Kley et al., 2009; Boets et al., 2010; Kobak, Jermacz \& Dzierżyńska-Białończyk, 2015). Perhaps due to its low activity (Van Riel et al., 2007; Beggel et al., 2016), changes in shelter occupancy in the presence of predators observed in various studies are ambiguous. In the presence of benthivorous fish (European bullhead), D. villosus was observed to reduce its presence in the open field (i.e., outside shelters) and activity considerably, from ca. $55 \%$ under control conditions to only $20 \%$ of the total experimental time (Sornom et al., 2012). However, in other studies, the reduction in open field occupancy or activity in the presence of predatory fish was only slight, though significant (Beggel et al., 2016; Jermacz et al., 2015a; Jermacz \& Kobak, 2017), or no response was observed at all Jermacz et al. (2017). These discrepancies might have resulted from the varying quality of shelters that could be occupied always or only in the presence of danger, as well as from the location of food. Sornom et al. (2012) found that in the presence of predators D. villosus decreased its activity and stayed more often in shelters made of holes in the solid substratum, whereas mesh shelters were always occupied irrespective of predator presence ( $>80 \%$ of the total time). In the studies by Jermacz et al. (2015a) and Jermacz \& Kobak (2017) gammarids spent more than $95 \%$ of the total experimental time in gravel substratum under predator absence, which allowed for only a small, though still significant change in response to predators. Jermacz et al. (2017) and Beggel et al. (2016) found that gammarids spent most of their time in gravel shelters even in the absence of predators. Jermacz \& Kobak (2017) observed gammarids to limit their occupation of the open space in the presence of predators when food was present in the direct vicinity of their shelters, whereas they kept exploring the unsheltered area in search of distant food sources. Thus, the presence of food can increase gammarid activity, which in turn can be reduced by the predation cue when the food is available at a short distance. 
D. villosus often occurs on hard and complex substrata, difficult to access by predators. Stone substratum was found to offer it more protection against fish predation compared to Gammarus fossarum and G. pulex, but this advantage disappeared on sand (Kinzler $\&$ Maier, 2006). In the wild, D. villosus was often found associated with zebra mussel (Dreissena polymorpha) colonies (e.g., Devin et al., 2003; Boets et al., 2010). Kobak, Jermacz \& Płachocki (2014) demonstrated that living dreissenids provided D. villosus with the most effective shelter against fish predators (the racer goby and Amur sleeper), compared to stones, macrophytes and shell litter. It should be noted that this shelter was also useful against a species without a common evolutionary history and exhibiting a different feeding strategy than the sympatric gobies (the Amur sleeper). This study demonstrated the positive effect of dreissenids on prey survival only in the case of $D$. villosus, but not for other invasive (P. robustoides) and native (Gammarus fossarum) species. However, in contrast to our studies, Beekey, McCabe \& Marsden (2004) showed that also native prey, including amphipods, experiences lower predation pressure in dreissenid beds.

Dreissenid beds can offer more effective protection than other substrata (Kobak, Jermacz $\&$ Płachocki, 2014), to less active species, such as D. villosus (Kobak et al., 2016), spending most time in the shelter (Beggel et al., 2016; Jermacz \& Kobak, 2017). This indicates that the presence of gregarious bivalves may promote the establishment of D. villosus. Dreissenid colonies, in contrast to other substratum types, form aggregations of objects bound with one another by byssal threads, hard to penetrate by fish (Kobak, Kakareko \& Poznańska, 2010) which, in association with the high attachment ability of D. villosus compared to other gammarids (Bacela-Spychalska, 2016) may make a mussel bed a perfect shelter for this species. Moreover, the hard substratum which supplies not only shelter and clinging opportunity, but also food resources, such as a colony of D. polymorpha, seems to be an optimal habitat for the invasive gammarids and may allow them to limit their exploration activity (Jermacz \& Kobak, 2017). Mussels provide both effective anti-predator protection (Beekey, McCabe \& Marsden, 2004; McCabe et al., 2006; Kobak, Jermacz \& Płachocki, 2014) and valuable food resources, such as organic-rich pseudofaeces and macroinvertebrate prey of increased abundance (Gergs \& Rothhaupt, 2008b; Kobak et al., 2016).

When shelters are limited (e.g., on sandy unvegetated nearshore bottoms in the wild), D. villosus exhibits an avoidance response to the predator cue, as shown by Hesselschwerdt et al. (2009) and Jermacz, Dzierżyńska-Białończyk \& Kobak (2017) in a Y-maze. This response was observed in the presence of hungry predators (starving for 3 days), likely to pose the highest danger to their potential prey. Thus, in the absence of suitable shelters and the presence of a direct danger, a temporary increase in activity and active avoidance seems to be an optimum response. In natural conditions, such a response is likely to result in leaving the predator area or finding the nearest shelter, after which the activity is reduced as the predation risk decreases.

\section{Aggregation forming}

Shelter choice depends not only on the substratum quality but also the presence or absence of conspecifics and heterospecifics gammarids (Jermacz et al., 2015a; Jermacz et al., 2017).

Laboratory experiments showed that $D$. villosus preferred shelters occupied by conspecifics 
over empty shelters and conspecifics located apart from shelters (Jermacz et al., 2017). Moreover, D. villosus exhibited a preference for shelters inhabited by conspecifics over those occupied by heterospecifics gammarids ( $P$. robustoides), thus forming single-species aggregations (Jermacz et al., 2017). Nevertheless, in the presence of predators, the selectivity of gammarids was reduced and they grouped alike with conspecifics and heterospecifics. The choice of the substratum already inhabited by other prey individuals is an example of aggregation behaviour combined with the benefits of sheltered conditions. The main advantage of the aggregation strategy is a reduction in the individual risk of predation (Hamilton, 1971). On the other hand, the weakness of this strategy is the facilitation of detection by a predator, especially by species using vision for prey detection (Ioannou \& Krause, 2008). However, when gammarids are aggregated under sheltered conditions, their detection seems to be difficult.

Notwithstanding the protective role of gammarid aggregations against predators, D. villosus did not increase the intensity of its grouping in shelters in the presence of predators (Sornom et al., 2012; Jermacz et al., 2017), in contrast to its relative, Pontogammarus robustoides (Jermacz et al., 2017). However, also in contrast to P. robustoides, D. villosus exposed to predation cues formed conspecific aggregations in open places, in the absence of shelters (Jermacz et al., 2017). The effectiveness of such a response as a protection against predators was demonstrated under laboratory conditions in which the racer goby avoided aggregated prey and consumed it less efficiently than singletons (Jermacz et al., 2017). This may be a consequence of the aforementioned clinging abilities of D. villosus (Bacela-Spychalska et al., 2013) and/or the hardness of its exoskeleton (Błoniska et al., 2015), which are greater than those of other gammarids, such as G. fossarum or P. robustoides (Bacela-Spychalska et al., 2013) and increase predator handling costs, thus contributing to the resistance of such aggregations against predators. On the other hand, the easiest prey for predators were single inactive individuals (Jermacz et al., 2017), indicating that this state should be avoided by gammarids seeking protection against predation.

\section{Depth selection}

For an aquatic organism, the choice of an appropriate habitat is also related to water depth. Fish predation pressure at shallow nearshore locations can be significantly lower than at deeper sites (Gliwicz, Soń \& Szynkarczyk, 2006; Perez et al., 2009). An experiment conducted by Kobak et al. (2017) in a $1 \mathrm{~m}$ deep tank with a depth gradient demonstrated that $D$. villosus in the presence of the racer goby relocated from the deepest zone, occupied preferentially under safe conditions, to the shallower bottom. Moreover, it also climbed upwards along the vertical tank walls and attached near the water surface (Kobak et al., 2017). Gobies are bottom-dwelling predators, rarely swimming freely in the water column; therefore the escape to the water column seems to be an effective response against them (Pinchuk et al., 2003). Our experimental results are reflected in field observations made in Lake Balaton occupied by Ponto-Caspian Gobiidae (Ferincz et al., 2016), where D. villosus occurs mainly on the stones near the water surface (Muskó et al., 2007). 


\section{External factors affecting gammarid responses to predators}

The responses of $D$. villosus to predator cues are modified by environmental pollution, such as increased heavy metal concentration (Sornom et al., 2012). The gammarids exposed to the solution of $500 \mu \mathrm{g}$ of cadmium per litre of water were observed to hide less often and be more active than the control individuals. Moreover, they no longer changed their behaviour in response to the presence of predators (Sornom et al., 2012).

Yet another potential factor that can potentially affect prey responses to predators is the presence of parasites, modifying host activity and it refuge use (Lafferty \& Morris, 1996; Perrot-Minnot, Kaldonski \& Cézilly, 2007; Kaldonski et al., 2008). D. villosus in European waters is parasitized by a microsporidian Cucumispora dikerogammari (Bacela-Spychalska et al., 2012). This parasite was found to affect the behaviour of its host, making it more active (Bacela-Spychalska, Rigaud \& Wattier, 2014), which could increase the detection probability and in consequence the survival chance of infected prey. Activity increase could potentially expose parasitized individuals to predator attacks and reduce their defence capabilities, though at present no evidence exists for that and further studies are needed on this topic.

Finally, it should be noted that not all responses of D. villosus to predators can be considered as anti-predator defences (Table 1). The predator diet can strongly modify the behaviour of gammarids and switch their responses from typical avoidance to even preference for predator scents (Jermacz, Dzierżyńska-Białończyk \& Kobak, 2017). See the chapter "Positive response of D. villosus to the predation cue" below for the details.

\section{D. villosus as prey}

Prey selection is a universal process, in which predators must choose among prey that differ in density and defence strategy. To optimize their fitness, predators should select those prey species whose abundance is high and hunting cost is low (Emlen, 1966). Many

variables can influence prey choice. Some of them are related to prey characteristics such as prey defence mechanisms, including behavioural (Andersson et al., 1986), morphological (Bollache et al., 2006), and physiological adaptations (Clinchy, Sheriff \& Zanette, 2013) or to environmental factors, such as habitat structure, food- quantity and temperature (Crowder \& Cooper, 1982). Effective predation also depends on predator hunting strategy and its flexibility (Grabowska et al., 2009).

Under experimental conditions D. villosus exhibited higher survival than other gammarids, including both native and invasive species, in the presence of diverse predators, such as the sympatric Ponto-Caspian gobies or the allopatric European bullhead and Amur sleeper (Kobak, Jermacz \& Płachocki, 2014; Błońska et al., 2015; Błońska et al., 2016; Beggel et al., 2016). Moreover, Kley et al. (2009) observed that the turbot (Lota lota) consumed fewer D. villosus compared to Gammarus roeselii. A similar result was shown by Błonska et al. (2015), who demonstrated that the racer goby always consumed preferentially native $G$. fossarum over D. villosus even if the gammarids were immobilized and unable to defend themselves. However, the goby did not exhibit any selectivity towards the waterborne chemical signals of native and invasive amphipods in a Y-maze (Błońska et al., 2015). On the other hand, Błonska et al. (2016) demonstrated that immobilized D. villosus and 


\begin{tabular}{|c|c|c|}
\hline Trait & Comments & References \\
\hline \multicolumn{3}{|c|}{ Constitutive traits (not changing in the presence of predators, but potentially protective) } \\
\hline Staying inactive in the shelter & $\begin{array}{l}\text { The species is less active than other gam- } \\
\text { marids }\end{array}$ & $\begin{array}{l}\text { Kley et al. (2009), Beggel et al. (2016) and } \\
\text { Kobak, Rachalewski \& Bacela-Spychalska } \\
\text { (2016) }\end{array}$ \\
\hline Aggregation in shelters & $\begin{array}{l}\text { No increase in the presence of predators, } \\
\text { but can contribute to the anti-predator pro- } \\
\text { tection }\end{array}$ & $\begin{array}{l}\text { Sornom et al. (2012), Jermacz et al. (2017) } \\
\text { and Jermacz, Dzierżyńska-Białończyk \& } \\
\text { Kobak (2017) }\end{array}$ \\
\hline Hard exoskeleton & Compared to other gammarids & Błońska et al. (2015) \\
\hline High clinging ability & $\begin{array}{l}\text { Potentially may facilitate forming aggrega- } \\
\text { tions resistant to predators }\end{array}$ & Bacela-Spychalska (2016) \\
\hline \multicolumn{3}{|l|}{ Changes induced by predators } \\
\hline \multirow[t]{4}{*}{ Increase in shelter occupancy time } & Ambiguous results: & \\
\hline & $\begin{array}{l}\text { Shown in hole shelters, not shown in mesh } \\
\text { shelters }\end{array}$ & Sornom et al. (2012) \\
\hline & $\begin{array}{l}\text { Shown in the vicinity of food, not shown } \\
\text { when food was distant }\end{array}$ & Jermacz \& Kobak (2017) \\
\hline & Weak but significant effect & $\begin{array}{l}\text { Jermacz et al. (2015a), Jermacz et al. (2015b) } \\
\text { and Beggel et al. (2016) }\end{array}$ \\
\hline $\begin{array}{l}\text { Utilization of coarse substrata (stones or zebra } \\
\text { mussel colonies) as shelters }\end{array}$ & $\begin{array}{l}\text { More efficient compared to other gammarid } \\
\text { species }\end{array}$ & $\begin{array}{l}\text { Kinzler \& Maier (2006), Kobak, Jermacz \& } \\
\text { Płachocki (2014) }\end{array}$ \\
\hline Active defence & $\begin{array}{l}\text { Better survival than that of G. fossarum in } \\
\text { the presence of fish and without shelters }\end{array}$ & Błońska et al. (2016) \\
\hline Activity reduction & $\begin{array}{l}\text { Shown in the presence of hole shelters, but } \\
\text { not with mesh shelters }\end{array}$ & Sornom et al. (2012) \\
\hline Active avoidance & $\begin{array}{l}\text { The scents of hungry predators (crayfish } \\
\text { and fish), starving for } 3 \text { days, in a Y maze }\end{array}$ & $\begin{array}{l}\text { Hesselschwerdt et al. (2009), Jermacz et al. } \\
\text { (2017) and Jermacz, Dzierżyńska-Białończyk } \\
\text { ¿ Kobak (2017) }\end{array}$ \\
\hline Active preference & $\begin{array}{l}\text { The scents of predators fed with } \\
\text { conspecifics, other gammarids or } \\
\text { chironomid larvae in a Y maze }\end{array}$ & $\begin{array}{l}\text { Jermacz et al. (2017) and Jermacz, } \\
\text { Dzierżyńska-Białończyk \& Kobak (2017) }\end{array}$ \\
\hline Selection of shallower depth & $\begin{array}{l}\text { In a } 1-m \text { depth gradient, in the presence of a } \\
\text { benthic predator }\end{array}$ & Kobak et al. (2017) \\
\hline Aggregation in the open field & & $\begin{array}{l}\text { Jermacz et al. (2017) and Jermacz, } \\
\text { Dzierżyńska-Białończyk \& Kobak (2017) }\end{array}$ \\
\hline Reduction in selectivity towards conspecifics & $\begin{array}{l}\text { Gammarids stop preferring conspecifics and } \\
\text { form groups independent of species }\end{array}$ & $\begin{array}{l}\text { Jermacz et al. (2017) and Jermacz, } \\
\text { Dzierżyńska-Białończyk \& Kobak (2017) }\end{array}$ \\
\hline Reduced consumption of food & $\begin{array}{l}\text { Shown when food had to be searched for, } \\
\text { not shown when food was present directly } \\
\text { in the shelter }\end{array}$ & Jermacz \& Kobak (2017) \\
\hline
\end{tabular}

native G. fossarum were equally selected by other goby species (the round goby Neogobius melanostomus and the tubenose goby Proterorhinus semilunaris) and the European bullhead, whereas mobile $D$. villosus specimens were avoided, irrespective of the presence or absence of shelters. This indicates that the effective behavioural anti-predator responses of $D$. villosus determined its survival under the pressure of these predator species (Błonska et al., 2016). The coarse and complex substratum (gravel, stones and zebra mussel colonies) also improved the survival of $D$. villosus compared to fine substrata and other gammarid species 
(Kinzler \& Maier, 2006; Kobak, Jermacz \& Płachocki, 2014). These results suggest that the mechanisms of the resistance of $D$. villosus to different predators may vary depending on their hunting mode, size and/or other traits.

The effectiveness of goby predation on D. villosus was described in detail by Jermacz et al. (2017). They demonstrated that under particular conditions, for example when gammarids were active or aggregated, the percentage of successful gobiid attacks was lower than $25 \%$. The predation efficiency exceeded $50 \%$ only in the case of single inactive gammarid individuals. Moreover, even when a fish already had a gammarid in its mouth, the prey was still able to escape without any visible damage. Such a low effectiveness of predation forces predatory species to multiply their effort to achieve the desired satiation level or choose alternative prey species if available. The necessity of feeding on prey generating high handling costs is unfavourable for the predator condition. For example, under laboratory conditions Błońska et al. (2015) demonstrated that gobiids fed with native G. fossarum or chironomid larvae grew significantly better than individuals forced to feed on D. villosus, and the latter group of fish exhibited weight loss after a 4-week exposure.

These observations confirm that $D$. villosus is a comparatively poor food item for its potential predators, and is likely to be avoided in the presence of alternative prey species, which can make it relatively safe in the natural environment. Generally, amphipods are considered as one of the most important elements of the diet of many fish species (MacNeil, Dick \& Elwood, 1999), however experimental results demonstrated that the role of $D$. villosus as food for the fish community could be significantly different from that of its native counterparts (Kobak, Jermacz \& Płachocki, 2014; Błońska et al., 2015; Błońska et al., 2016; Beggel et al., 2016), often replaced by the alien species (Dick \& Platvoet, 2000; Dick, Platvoet \& Kelly, 2002; Grabowski et al., 2006).

\section{Positive response of $D$. villosus to the predation cue}

In general, a chemical signal indicating predator presence induces a defence response responsible for the reduction in predation risk (Brönmark \& Hansson, 2000; Ferrari, Wisenden \& Chivers, 2010). However, in the case of omnivorous species, capable of feeding on predator faeces or their dead bodies, or partly sharing their diet, a predation signal does not always indicate only a danger and, as a consequence, does not always induce a defence response. Such a unique situation takes place in the case of D. villosus as it actively avoided the scent of hungry predators in a Y-maze, but did not exhibit an avoidance reaction to the predation cues emitted by predators fed with chironomids or other gammarids (including conspecifics) (Jermacz, Dzierżyńska-Białończyk \& Kobak, 2017). On the contrary, it showed an active preference, moving towards the scent of satiated predators in a Y-maze (Jermacz, Dzierżyńska-Białończyk \& Kobak, 2017). A similar response was induced by the presence of cues released by crushed conspecifics and other gammarid species. This reaction suggests that this omnivorous and cannibalistic species is able to use such a signal not as a predation cue, but as a source of information about the location of a feeding ground. As shown in the above sections of this review, D. villosus is characterized by an effective defence strategy (Kobak, Jermacz \& Płachocki, 2014; Błońska et al., 2015; Błońska et al., 2016; Jermacz et al., 2017), therefore being relatively safe in the presence of 
predators, especially when alternative prey items are available in the vicinity (Jermacz et al., 2015a; Błońska et al., 2016). In such a situation, D. villosus may follow a predator to feed on its faeces or sense wounded invertebrates as being its potential prey. A similar trade-off between predator avoidance and foraging was observed in the case of Gammarus pulex, which in the presence of food did not respond to the predation signal, contrary to the situation when it was exposed only to predator kairomones (Szokoli et al., 2015).

\section{Costs of the anti-predator responses of $D$. villosus}

Anti-predatory defences of prey organisms usually result in considerable energetic costs of the development of additional structures, selection of suboptimal habitats and/or decreased feeding due to the higher vigilance focused on predator detection (Hawlena \& Schmitz, 2010; Sheriff \& Thaler, 2014). This may result in growth reduction (Janssens \& Stoks, 2013), weaker condition (Slos \& Stoks, 2008) and/or finally even mortality (McCauley, Rowe \& Fortin, 2011). The impact of the presence of predators on the feeding of D. villosus was checked by Jermacz \& Kobak (2017). The gammarids considerably limited their feeding in the presence of predators (by $95 \%$ and $74 \%$ depending on the location of food, placed in the direct vicinity of shelters or away from them, respectively). Surprisingly, this response was even stronger than that of the related species P. robustoides ( $77 \%$ and $33 \%$, respectively), though the latter seems to be more susceptible to predation pressure. On the other hand, no decrease in feeding was observed when single gammarids did not have to search for their food, having it available directly in their shelters. This shows that the aforementioned limitation of feeding in the open field resulted from the limited activity of gammarids (when food was located close to the shelter) or their increased vigilance in the open field (when food was distant from the shelter and no reduction in the search time was observed).

Nevertheless, the most important result of the study by Jermacz \& Kobak (2017) was the demonstration that the growth rate of $D$. villosus supplied with food in their shelters (over a period of 2 weeks) was unaffected by the presence of predators. On the other hand, $P$. robustoides under the same conditions significantly reduced its growth rate by ca. $60 \%$ when exposed to predation cues (Jermacz \& Kobak, 2017). Reduction in growth under predation risk was also observed in an amphipod Hyalella azteca, accompanying its induced morphological adaptations resulting in lower predator pressure (James \& McClintock, 2017). This confirms the relatively high resistance of $D$. villosus to non-consumptive predator effects and shows that it may thrive in a good physiological condition under predatory pressure.

Resistance of $D$. villosus to predator non-consumptive effects was also confirmed by Richter et al. (2018), who did not observe any disturbance of gammarid feeding behaviour under the pressure of a benthivorous fish, the European bullhead (Cottus gobio). In contrast, another gammarid species (G. pulex) reduced its consumption in the presence of C. gobio kairomones (Abjörnsson et al., 2000). Lagrue, Besson \& Lecerf (2015) have shown that the abundance of armoured detritivore prey did not decrease in the presence of predators, in contrast to that of non-armoured species. D. villosus is more armoured than other gammarids (Błońska et al., 2015), and thus the consequence of trade-offs between 
behavioural and morphological defences, such as the cost of the anti-predator responses of D. villosus seems to be less pronounced than that of other gammarids.

\section{Ecological significance of the anti-predator strategy of $D$. villosus}

We have shown that D. villosus is capable of flexible predator recognition (Jermacz, Dzierżyńska-Białończyk \& Kobak, 2017) allowing the species to respond to both novel and known dangers. It seems unlikely that it may benefit from the naïvety of local predators in central and western Europe, as they are used to preying on native gammarids (MacNeil, Dick \& Elwood, 1999; MacNeil, Elwood \& Dick, 1999) and not very selective with regard to their benthic food, consuming also large quantities of alien amphipods (Rezsu \& Specziár, 2006; Eckmann et al., 2008). Moreover, predators of Ponto-Caspian origin, sympatric to the gammarids, such as several species of gobiid fish, have also invaded the same regions and co-occur with $D$. villosus in most of its current range, and include it in their diet (Grabowska \& Grabowski, 2005; Borza, Eros \& Oertel, 2009; Brandner et al., 2013). Therefore, its ability to easily recognize potential dangers may be one of the traits facilitating its establishment in invaded areas.

The efficient defence mechanisms of $D$. villosus make this species relatively resistant to predation (Kobak, Jermacz \& Płachocki, 2014; Jermacz et al., 2017; Jermacz, DzierżyńskaBiałonczyk \& Kobak, 2017), which may help it in its competition with other gammarids (Jermacz et al., 2015a; Beggel et al., 2016). Other, less resistant and more often consumed species are preferentially removed from the environment by predators and must spend more energy and time on anti-predator vigilance, whereas D. villosus, as the least preferred potential food, may thrive in the presence of predators with no negative effect on its growth (Jermacz \& Kobak, 2017). Moreover, its aggressive behaviour may force competing gammarid species to less suitable habitats (Platvoet et al., 2009; Jermacz et al., 2015a) or make them swim more often in the water column, which further exposes them to fish predation (e.g., Jermacz et al., 2015a; Beggel et al., 2016). In addition to direct intra-guild predation and competition for food, this displacement from shelter is likely to be another factor making D. villosus an efficient competitor displacing other species from the areas in which it appears. Negative interactions with $D$. villosus make other gammarids avoid the presence of the stronger competitor, increasing their migrations to new areas and switching to different habitats (Dick, Platvoet \& Kelly, 2002; Hesselschwerdt, Necker \& Wantzen, 2008; Platvoet et al., 2009; Jermacz et al., 2015a; Kobak et al., 2016).

Nevertheless, the nature of interactions between D. villosus and its related species is far more complex. The presence of predators does have an impact on D. villosus behaviour (Jermacz, Dzierżyńska-Białończyk \& Kobak, 2017; Kobak et al., 2017; Jermacz et al., 2017) and may reduce its interspecific aggression, allowing the competing species to stay in its presence. Jermacz et al. (2015a) have demonstrated that another gammarid P. robustoides is easily displaced from habitats preferred by both species in a safe environment, but the presence of predatory fish changes the situation, allowing $P$. robustoides to stay in the area co-occupied by $D$. villosus. It is difficult to distinguish whether this is due to the reduction in $D$. villosus aggression or the higher substratum affinity of $P$. robustoides in the presence of predators (selecting the vicinity of the stronger competitor as the lesser evil), 
or both. Nevertheless, individuals of both species can take advantage of staying in a group and reduce the probability of a successful predator attack (Jermacz et al., 2017). This also shows how important it is to consider the effect of predators when studying competitive interactions between species because the consequences of competition in a predator-free situation, which is very unlikely in the wild, may be easily overestimated.

Moreover, as the reduction in the feeding rate of $D$. villosus in the presence of predators was observed by Jermacz \& Kobak (2017), it is likely that the predatory impact of this gammarid on the local community can also be lower than expected on the basis of experiments conducted in fishless conditions. This confirms the results of the field studies in the River Rhine (Hellmann et al., 2015; Hellmann et al., 2017; Koester, Bayer \& Gergs, 2016) and can explain their discrepancy with some laboratory experiments, indicating the strong predatory impact of D. villosus on invertebrates (Dick \& Platvoet, 2000; MacNeil \& Platvoet, 2005).

Unexpectedly, despite the high consumption of D. villosus commonly observed in the field (Kelleher et al., 1998; Grabowska \& Grabowski, 2005; Eckmann et al., 2008; Borza, Eros \& Oertel, 2009; Brandner et al., 2013; Czarnecka, Pilotto \& Pusch, 2014), it was experimentally demonstrated that its dominance may in fact decrease the quality of food conditions for fish due to the higher difficulty of capturing and handling, leading to poor growth on a diet based on this species, compared to the diets consisting of native gammarids or chironomid larvae (Błońska et al., 2015). Thus, although fish feed on D. villosus in the areas invaded by this species, it seems they would have thrived much better if this invasion had not occurred and other gammarid species (usually displaced by the invader) had been available as alternative food (Błońska et al., 2015).

\section{CONCLUSION}

We have shown $D$. villosus as a species with efficient anti-predation mechanisms (both behavioural modifications and constitutive traits), relatively safe from predators and bearing lower costs of their non-consumptive effects (as indicated by its growth unaffected by the presence of fish), compared to related taxa. It can recognize sympatric and novel fish predators independent of their diet, though its precise responses are fine-tuned on the basis of food consumed by a predator, and can range from avoidance to preference. Sometimes $D$. villosus can even be attracted to a predator scent, probably utilizing their presence to locate potential food sources. Defence mechanisms of this species include activity reduction, aggregation and migration. In general, single immobile individuals outside the shelter are the most susceptible to predation. Therefore, threatened individuals try: (1) to stay in the shelter, at best co-occupied by other specimens; (2) if this is not possible, to move in search of a shelter; (3) if shelters are difficult to find, to aggregate with conspecifics, used as a substitute shelter; (4) if conspecifics are also difficult to locate (e.g., at a low density), to relocate to safer areas, e.g., away from the predator scent or to the shallower bottom. These traits are likely to give it a strong advantage in competition with similar species, both natives and other invaders, and contribute to its invasive potential. Moreover, we have demonstrated the strong importance of predator effects on interactions 
among gammarid species involving $D$. villosus, which cannot be neglected in future studies on this topic. It is likely that under predatory pressure the competitive impact of $D$. villosus on other gammarids as well as its predation on zoobenthos organisms are reduced, altering its impact on local communities.

\section{ACKNOWLEDGEMENTS}

We are grateful to Mrs. Hazel Pearson for language corrections.

\section{ADDITIONAL INFORMATION AND DECLARATIONS}

\section{Funding}

Our study was supported by the grants of the National Science Centre, Poland No. 2013/09/N/NZ8/03191 and 2016/21/B/NZ8/00418. The funders had no role in study design, data collection and analysis, decision to publish, or preparation of the manuscript.

\section{Grant Disclosures}

The following grant information was disclosed by the authors:

National Science Centre, Poland: No. 2013/09/N/NZ8/03191, 2016/21/B/NZ8/00418.

\section{Competing Interests}

The authors declare there are no competing interests.

\section{Author Contributions}

- Eukasz Jermacz authored or reviewed drafts of the paper, approved the final draft.

- Jarosław Kobak prepared figures and/or tables, authored or reviewed drafts of the paper, approved the final draft.

\section{Data Availability}

The following information was supplied regarding data availability:

The research in this article did not generate any data or code, this is a comprehensive literature review of the responses of an invasive amphipod Dikerogammarus villosus to predator signal.

\section{REFERENCES}

Abjörnsson K, Dahl J, Nyström P, Brönmark C. 2000. Influence of predator and dietary chemical cues on the behaviour and shredding efficiency of Gammarus pulex. Aquatic Ecology 34:379-387 DOI 10.1023/A:1011442331229.

Åbjörnsson K, Hansson L-A, Brönmark C. 2004. Responses of prey from habitats with different predator regimes: local adaptation and heritability. Ecology 85:1859-1866 DOI 10.1890/03-0074.

Åbjörnsson K, Wagner B, Axelsson A, Bjerselius R, Olsen KH. 1997. Responses of Acilius sulcatus (Coleoptera: Dytiscidae) to chemical cues from perch (Perca fluviatilis). Oecologia 111:166-171 DOI 10.1007/s004420050221. 
Andersson KG, Brönmark C, Herrmann J, Malmqvist B, Otto C, Sjörström P, Bronmark C. 1986. Presence of sculpins (Cottus gobio) reduces drift and activity of Gammarus pulex (Amphipoda). Hydrobiologia 133:209-215 DOI 10.1007/BF00005592.

Bacela-Spychalska K. 2016. Attachment ability of two invasive amphipod species may promote their spread by overland transport. Aquatic Conservation: Marine and Freshwater Ecosystems 26:196-201 DOI 10.1002/aqc.2565.

Bacela-Spychalska K, Grabowski M, Rewicz T, Konopacka A, Wattier R. 2013. The 'killer shrimp' Dikerogammarus villosus (Crustacea, Amphipoda) invading Alpine lakes: overland transport by recreational boats and scuba-diving gear as potential entry vectors? Aquatic Conservation: Marine and Freshwater Ecosystems 23:606-618 DOI 10.1002/aqc.2329.

Bacela-Spychalska K, Rigaud T, Wattier RA. 2014. A co-invasive microsporidian parasite that reduces the predatory behaviour of its host Dikerogammarus villosus (Crustacea, Amphipoda). Parasitology 141:254-258 DOI 10.1017/S0031182013001510.

Bacela-Spychalska K, Wattier RA, Genton C, Rigaud T. 2012. Microsporidian disease of the invasive amphipod Dikerogammarus villosus and the potential for its transfer to local invertebrate fauna. Biological Invasions 14:1831-1842 DOI 10.1007/s10530-012-0193-1.

Banks PB, Dickman CR. 2007. Alien predation and the effects of multiple levels of prey naiveté. Trends in Ecology \& Evolution 22:229-230 DOI 10.1016/j.tree.2007.02.006.

Becker J, Ortmann C, Wetzel MA, Koop JHE. 2016. Metabolic activity and behavior of the invasive amphipod Dikerogammarus villosus and two common Central European gammarid species (Gammarus fossarum, Gammarus roeselii): low metabolic rates may favor the invader. Comparative Biochemistry and Physiology-Part A: Molecular and Integrative Physiology 191:119-126 DOI 10.1016/j.cbpa.2015.10.015.

Beekey MA, McCabe DJ, Marsden JE. 2004. Zebra mussels affect benthic predator foraging success and habitat choice on soft sediments. Oecologia 141:164-170 DOI 10.1007/s00442-004-1632-1.

Beggel S, Brandner J, Cerwenka AF, Geist J. 2016. Synergistic impacts by an invasive amphipod and an invasive fish explain native gammarid extinction. BMC Ecology 16:32 DOI 10.1186/s12898-016-0088-6.

Bij de Vaate A, Jazdzewski K, Ketelaars HAM, Gollasch S, Van der Velde G. 2002. Geographical patterns in range extension of Ponto-Caspian macroinvertebrate species in Europe. Canadian Journal of Fisheries and Aquatic Sciences 1174:1159-1174 DOI 10.1139/f02-098.

Błońska D, Grabowska J, Kobak J, Jermacz Ł, Bącela-Spychalska K. 2015. Feeding preferences of an invasive Ponto-Caspian goby for native and non-native gammarid prey. Freshwater Biology 60:2187-2195 DOI 10.1111/fwb.12647.

Błońska D, Grabowska J, Kobak J, Rachalewski M, Bącela-Spychalska K. 2016. Fish predation on sympatric and allopatric prey-a case study of Ponto-Caspian gobies, European bullhead and amphipods. Limnologica-Ecology and Management of Inland Waters 61:1-6 DOI 10.1016/j.limno.2016.06.003. 
Boeing WJ, Ramcharan CW, Riessen HP. 2006. Clonal variation in depth distribution of Daphnia pulex in response to predator kairomones. Archiv für Hydrobiologie 166:241-260 DOI 10.1127/0003-9136/2006/0166-0241.

Boets P, Lock K, Messiaen M, Goethals PLM. 2010. Combining data-driven methods and lab studies to analyse the ecology of Dikerogammarus villosus. Ecological Informatics 5:133-139 DOI 10.1016/j.ecoinf.2009.12.005.

Bollache L, Kaldonski N, Troussard J-P, Lagrue C, Rigaud T. 2006. Spines and behaviour as defences against fish predators in an invasive freshwater amphipod. Animal Behaviour 72:627-633 DOI 10.1016/j.anbehav.2005.11.020.

Borza P, Eros T, Oertel N. 2009. Food resource partitioning between two invasive gobiid species (Pisces, Gobiidae) in the littoral zone of the river danube, Hungary. International Review of Hydrobiology 94:609-621 DOI 10.1002/iroh.200911134.

Brandner J, Auerswald K, Cerwenka AF, Schliewen UK, Geist J. 2013. Comparative feeding ecology of invasive Ponto-Caspian gobies. Hydrobiologia 703:113-131 DOI 10.1007/s10750-012-1349-9.

Brönmark C, Hansson L. 2000. Chemical communication in aquatic systems: an introduction. Oikos 88:103-109 DOI 10.1034/j.1600-0706.2000.880112.x.

Chivers DP, Smith RJF. 1998. Chemical alarm signalling in aquatic predator-prey systems: a review and prospectus. Ecoscience 5:338-352

DOI 10.1080/11956860.1998.11682471.

Chivers DP, Wisenden BD, Smith RJF. 1996. Damselfly larvae learn to recognize predators from chemical cues in the predator's diet. Animal Behaviour 52:315-320 DOI 10.1006/anbe.1996.0177.

Clinchy M, Sheriff MJ, Zanette LY. 2013. Predator-induced stress and the ecology of fear. Functional Ecology 27:56-65 DOI 10.1111/1365-2435.12007.

Creel S, Christianson D. 2008. Relationships between direct predation and risk effects. Trends in Ecology and Evolution 23:194-201 DOI 10.1016/j.tree.2007.12.004.

Crowder LB, Cooper WE. 1982. Habitat structural complexity and the interaction between bluegills and their prey. Ecology 63:1802-1813 DOI 10.2307/1940122.

Czarnecka M. 2016. Coarse woody debris in temperate littoral zones: implications for biodiversity, food webs and lake management. Hydrobiologia 767:13-25 DOI 10.1007/s10750-015-2502-z.

Czarnecka M, Pilotto F, Pusch MT. 2014. Is coarse woody debris in lakes a refuge or a trap for benthic invertebrates exposed to fish predation? Freshwater Biology 59:2400-2412 DOI 10.1111/fwb.12446.

Czarnecka M, Poznańska M, Kobak J, Wolnomiejski N. 2009. The role of solid waste materials as habitats for macroinvertebrates in a lowland dam reservoir. Hydrobiologia 635:125-135 DOI 10.1007/s10750-009-9905-7.

Czarnołęski M, Müller T, Adamus K, Ogorzelska G, Sog M. 2010. Injured conspecifics alter mobility and byssus production in zebra mussels Dreissena polymorpha. Fundamental and Applied Limnology/Archiv für Hydrobiologie 176:269-278 DOI 10.1127/1863-9135/2010/0176-0269.

DAISIE. 2009. Handbook of Alien Species in Europe. Dordrecht: Springer Netherlands. 
Dalesman S, Rundle SD, Cotton PA. 2007. Predator regime influences innate antipredator behaviour in the freshwater gastropod Lymnaea stagnalis. Freshwater Biology 52:2134-2140 DOI 10.1111/j.1365-2427.2007.01843.x.

De Meester L, Dawidowicz P, Loose C, Van Gool E. 1999. Ecology and evolution of predator-induced behavior of zooplankton: depth selection behavior and diel vertical migration. In: Tollrian R, Harvel CD, eds. The ecoloy and evolution of inducible defenses. Princeton: Princeton University Press, 160-176.

Devin S, Beisel JN. 2007. Biological and ecological characteristics of invasive species: a gammarid study. Biological Invasions 9:13-24.

Devin S, Piscart C, Beisel JN, Moreteau JC. 2003. Ecological traits of the amphipod invader Dikerogammarus villosus on a mesohabitat scale. Archiv für Hydrobiologie 158:43-56 DOI 10.1127/0003-9136/2003/0158-0043.

Dick JTA, Platvoet D. 2000. Invading predatory crustacean Dikerogammarus villosus eliminates both native and exotic species. Proceedings of the Royal Society B: Biological Sciences 267:977-983 DOI 10.1098/rspb.2000.1099.

Dick JTA, Platvoet D, Kelly DW. 2002. Predatory impact of the freshwater invader Dikerogammarus villosus (Crustacea: Amphipoda). Canadian Journal of Fisheries and Aquatic Sciences 59:1078-1084 DOI 10.1139/f02-074.

Dunn AM, Dick JTA, Hatcher MJ. 2008. The less amorous Gammarus: predation risk affects mating decisions in Gammarus duebeni (Amphipoda). Animal Behaviour 76:1289-1295 DOI 10.1016/j.anbehav.2008.06.013.

Dzialowski AR, Lennon JT, O’Brien WJ, Smith VH. 2003. Predator-induced phenotypic plasticity in the exotic cladoceran Daphnia lumholtzi. Freshwater Biology 48:1593-1602 DOI 10.1046/j.1365-2427.2003.01111.x.

Eckmann R, Mörtl M, Baumgärtner D, Berron C, Fischer P, Schleuter D, Weber A. 2008. Consumption of amphipods by littoral fish after the replacement of native Gammarus roeseli by invasive Dikerogammarus villosus in Lake Constance. Aquatic Invasions 3:187-191 DOI 10.3391/ai.2008.3.2.9.

Emlen JM. 1966. The role of time and energy in food preference. The American Naturalist 100:611-617 DOI 10.1086/282455.

Ferincz Á, Staszny Á, Weiperth A, Takács P, Urbányi B, Vilizzi L, Paulovits G, Copp GH. 2016. Risk assessment of non-native fishes in the catchment of the largest Central-European shallow lake (Lake Balaton, Hungary). Hydrobiologia 780:85-97 DOI 10.1007/s10750-016-2657-2.

Ferrari MCO, Gonzalo A, Messier F, Chivers DP. 2007. Generalization of learned predator recognition: an experimental test and framework for future studies. Proceedings of the Royal Society B: Biological Sciences 274:1853-1859 DOI 10.1098/rspb.2007.0297.

Ferrari MCO, Wisenden BD, Chivers DP. 2010. Chemical ecology of predator-prey interactions in aquatic ecosystems: a review and prospectus. The present review is one in the special series of reviews on animal-plant interactions. Canadian Journal of Zoology 88:698-724 DOI 10.1139/Z10-029. 
Gergs R, Rothhaupt K-O. 2008a. Effects of zebra mussels on a native amphipod and the invasive Dikerogammarus villosus: the influence of biodeposition and structural complexity. Journal of North American Benthological Society 27:541-548 DOI 10.1899/07-151.1.

Gergs R, Rothhaupt K-O. 2008b. Feeding rates, assimilation efficiencies and growth of two amphipod species on biodeposited material from zebra mussels. Freshwater Biology 53:2494-2503 DOI 10.1111/j.1365-2427.2008.02077.x.

Gergs R, Rothhaupt K-O. 2015. Invasive species as driving factors for the structure of benthic communities in Lake Constance, Germany. Hydrobiologia 746:245-254 DOI 10.1007/s10750-014-1931-4.

Gerking SD. 1994. Feeding ecology of fish. San Diego: Academic Press.

Glazier DS, Butler EM, Lombardi SA, Deptola TJ, Reese AJ, Satterthwaite EV. 2011. Ecological effects on metabolic scaling: Amphipod responses to fish predators in freshwater springs. Ecological Monographs 81:599-618 DOI 10.1890/11-0264.1.

Gliwicz ZM. 1994. Relative significance of direct and indirect effects of predation by planktivorous fish on zooplankton. Hydrobiologia 272:201-210 DOI 10.1007/BF00006521.

Gliwicz ZM. 2005. Food web interactions: why are they reluctant to be manipulated? Plenary Lecture. Verhandlungen Internationale Vereinigung für Theoretische und Angewandte Limnologie 29:73-88 DOI 10.1080/03680770.2005.11901976.

Gliwicz ZM, Słoń J, Szynkarczyk I. 2006. Trading safety for food: evidence from gut contents in roach and bleak captured at different distances offshore from their daytime littoral refuge. Freshwater Biology 51:823-839 DOI 10.1111/j.1365-2427.2006.01530.x.

Grabowska J, Grabowski M. 2005. Diel-feeding activity in early summer of racer goby Neogobius gymnotrachelus (Gobiidae): a new invader in the Baltic basin. Journal of Applied Ichthyology 21:282-286 DOI 10.1111/j.1439-0426.2005.00676.x.

Grabowska J, Grabowski M, Pietraszewski D, Gmur J. 2009. Non-selective predatorthe versatile diet of Amur sleeper (Perccottus glenii Dybowski, 1877) in the Vistula River (Poland), a newly invaded ecosystem. Journal of Applied Ichthyology 25:451-459 DOI 10.1111/j.1439-0426.2009.01240.x.

Grabowski M, Bącela K, Konopacka A. 2007. How to be an invasive gammarid (Amphipoda: Gammaroidea) — comparison of life history traits. Hydrobiologia 590:75-84 DOI 10.1007/s10750-007-0759-6.

Grabowski M, Konopacka A, Jazdzewski K, Janowska E. 2006. Invasions of alien gammarid species and retreat of natives in the Vistula Lagoon (Baltic Sea, Poland). Helgoland Marine Research 60:90-97 DOI 10.1007/s10152-006-0025-8.

Gusev AA, Guseva DO, Sudnik SA. 2017. New record of the Ponto-Caspian gammarid Dikerogammarus villosus (Sowinsky, 1894) in the southeastern part of the Baltic Sea (Kaliningrad oblast, Russia). Russian Journal of Biological Invasions 8:218-225 DOI 10.1134/S2075111717030055.

Hamilton WD. 1971. Geometry for the selfish herd. Journal of Theoretical Biology 31:295-311 DOI 10.1016/0022-5193(71)90189-5. 
Hawlena D, Schmitz OJ. 2010. Physiological stress as a fundamental mechanism linking predation to ecosystem functioning. The American Naturalist 176:537-556 DOI 10.1086/656495.

Hellmann C, Schöll F, Worischka S, Becker J, Winkelmann C. 2017. Riverspecific effects of the invasive amphipod Dikerogammarus villosus (Crustacea: Amphipoda) on benthic communities. Biological Invasions 19:381-398 DOI 10.1007/s10530-016-1286-z.

Hellmann C, Worischka S, Mehler E, Becker J, Gergs R, Winkelmann C. 2015. The trophic function of Dikerogammarus villosus (Sowinsky, 1894) in invaded rivers: a case study in the Elbe and Rhine. Aquatic Invasions 10:385-397 DOI 10.3391/ai.2015.10.4.03.

Hesselschwerdt J, Necker J, Wantzen KM. 2008. Gammarids in Lake Constance: habitat segregation between the invasive Dikerogammarus villosus and the indigenous Gammarus roeselii. Fundamental and Applied Limnology/Archiv für Hydrobiologie 173:177-186 DOI 10.1127/1863-9135/2008/0173-0177.

Hesselschwerdt J, Tscharner S, Necker J, Wantzen KM. 2009. A local gammarid uses kairomones to avoid predation by the invasive crustaceans Dikerogammarus villosus and Orconectes limosus. Biological Invasions 11:2133-2140 DOI 10.1007/s10530-009-9492-6.

Holomuzki JR, Hoyle JD. 1988. Effect of predatory fish presence on habitat use and diel movement of the stream amphipod, Gammarus minus. Freshwater Biology 24:509-517 DOI 10.1111/j.1365-2427.1990.tb00728.x.

Ioannou CC, Krause J. 2008. Searching for prey: the effects of group size and number. Animal Behaviour 75:1383-1388 DOI 10.1016/j.anbehav.2007.09.012.

James WR, McClintock JB. 2017. Anti-predator responses of amphipods are more effective in the presence of conspecific chemical cues. Hydrobiologia 797:277-288 DOI 10.1007/s10750-017-3191-6.

Janssens L, Stoks R. 2013. Predation risk causes oxidative damage in prey. Biology Letters 9:Article 20130350 DOI 10.1098/rsbl.2013.0350.

Jermacz Ł, Andrzejczak J, Arczyńska E, Zielska J, Kobak J. 2017. An enemy of your enemy is your friend: impact of predators on aggregation behavior of gammarids. Ethology 123:627-639 DOI 10.1111/eth.12635.

Jermacz Ł, Dzierzyńska A, Kakareko T, Poznańska M, Kobak J. 2015a. The art of choice: predation risk changes interspecific competition between freshwater amphipods. Behavioral Ecology 26:656-664 DOI 10.1093/beheco/arv009.

Jermacz Ł, Dzierzyńska A, Poznańska M, Kobak J. 2015b. Experimental evaluation of preferences of an invasive Ponto-Caspian gammarid Pontogammarus robustoides (Amphipoda, Gammaroidea) for mineral and plant substrata. Hydrobiologia 746:209-221 DOI 10.1007/s10750-014-1963-9.

Jermacz Ł, Dzierżyńska-Białończyk A, Kobak J. 2017. Predator diet, origin or both? Factors determining responses of omnivorous amphipods to predation cues. Hydrobiologia 785:173-184 DOI 10.1007/s10750-016-2917-1. 
Jermacz Ł, Kobak J. 2017. Keep calm and don’t stop growing: non-consumptive effects of a sympatric predator on two invasive Ponto-Caspian gammarids Dikerogammarus villosus and Pontogammarus robustoides. PLOS ONE 12:e182481 DOI 10.1371/journal.pone.0182481.

Kaldonski N, Perrot-Minnot M-J, Motreuil S, Cézilly F. 2008. Infection with acanthocephalans increases the vulnerability of Gammarus pulex (Crustacea, Amphipoda) to non-host invertebrate predators. Parasitology 135:627-632 DOI 10.1017/S003118200800423X.

Kelleher B, Bergers PJM, Van den Brink FWB, Giller PS, Van der Velde G, De Vaate AB. 1998. Effects of exotic amphipod invasions on fish diet in the Lower Rhine. Fundamental and Applied Limnology 143:363-382 DOI 10.1127/archiv-hydrobiol/143/1998/363.

Kinzler W, Kley A, Mayer G, Waloszek D, Maier G. 2009. Mutual predation between and cannibalism within several freshwater gammarids: Dikerogammarus villosus versus one native and three invasives. Aquatic Ecology 43:457-464 DOI 10.1007/s10452-008-9206-7.

Kinzler W, Maier G. 2006. Selective predation by fish: a further reason for the decline of native gammarids in the presence of invasives? Journal of Limnology 65:27-34 DOI 10.4081/jlimnol.2006.27.

Kley A, Kinzler W, Schank Y, Mayer G, Waloszek D, Maier G. 2009. Influence of substrate preference and complexity on co-existence of two non-native gammarideans (Crustacea: Amphipoda). Aquatic Ecology 43:1047-1059 DOI 10.1007/s10452-009-9242-y.

Kobak J, Jermacz Ł, Dzierżyńska-Białończyk A. 2015. Substratum preferences of the invasive killer shrimp Dikerogammarus villosus. Journal of Zoology 297:66-76 DOI 10.1111/jzo.12252.

Kobak J, Jermacz $Ł$, Płąchocki D. 2014. Effectiveness of zebra mussels to act as shelters from fish predators differs between native and invasive amphipod prey. Aquatic Ecology 48:397-408 DOI 10.1007/s10452-014-9492-1.

Kobak J, Jermacz Ł, Rutkowska D, Pawłowska K, Witkowska L, Poznańska M. 2017. Impact of predators and competitors on the depth selection by two invasive gammarids. Journal of Zoology 301:174-183 DOI 10.1111/jzo.12409.

Kobak J, Kakareko T, Poznańska M. 2010. Changes in attachment strength and aggregation of zebra mussel, Dreissena polymorpha in the presence of potential fish predators of various species and size. Hydrobiologia 644:195-206 DOI 10.1007/s10750-010-0113-2.

Kobak J, Poznańska M, Jermacz Ł, Kakareko T, Prądzynski D, Łodygowska M, Montowska K, Bącela-Spychalska K. 2016. Zebra mussel beds: an effective feeding ground for Ponto-Caspian gobies or suitable shelter for their prey? PeerJ 4:e2672 DOI 10.7717/peerj.2672.

Kobak J, Rachalewski M, Bącela-Spychalska K. 2016. Conquerors or exiles? Impact of interference competition among invasive Ponto-Caspian gammarideans on their dispersal rates. Biological Invasions 18:1953-1965 DOI 10.1007/s10530-016-1140-3. 
Kobak J, Ryńska A. 2014. Environmental factors affecting behavioural responses of an invasive bivalve to conspecific alarm cues. Animal Behaviour 96:177-186 DOI 10.1016/j.anbehav.2014.08.014.

Koester M, Bayer B, Gergs R. 2016. Is Dikerogammarus villosus (Crustacea, Gammaridae) a 'killer shrimp' in the River Rhine system? Hydrobiologia 768:299-313 DOI 10.1007/s10750-015-2558-9.

Koperski P. 1997. Changes in feeding behaviour of the larvae of the damselfly Enallagma cyathigerum in response to stimuli from predators. Ecological Entomology 22:167-175 DOI 10.1046/j.1365-2311.1997.00058.x.

Korpi NL, Wisenden BD. 2001. Learned recognition of novel predator odour by zebra danios, Danio rerio, Following time-shifted presentation of alarm cue and predator odour. Environmental Biology of Fishes 61:205-211 DOI 10.1023/A:1011091426030.

Krisp H, Maier G. 2005. Consumption of macroinvertebrates by invasive and native gammarids: a comparison. Journal of Limnology 64:55-59

DOI 10.4081/jlimnol.2005.55.

Lafferty KD, Morris AK. 1996. Altered behavior of parasitized killifish increases susceptibility to predation by bird final hosts. Ecology 77:1390-1397 DOI 10.2307/2265536.

Lagrue C, Besson AA, Lecerf A. 2015. Interspecific differences in antipredator strategies determine the strength of non-consumptive predator effects on stream detritivores. Oikos 124:1589-1596 DOI 10.1111/oik.02272.

Lass S, Spaak P. 2003. Chemically induced anti-predator defences in plankton: a review. Hydrobiologia 491:221-239 DOI 10.1023/A:1024487804497.

Lima SLS, Dill LML. 1990. Behavioral decisions made under the risk of predation: a review and prospectus. Canadian Journal of Zoology 68:619-640 DOI 10.1139/z90-092.

Maazouzi C, Piscart C, Pihan J-C, Masson G. 2009. Effect of habitat-related resources on fatty acid composition and body weight of the invasive Dikerogammarus villosus in an artificial reservoir. Fundamental and Applied Limnology/Archiv für Hydrobiologie 175:327-338 DOI 10.1127/1863-9135/2009/0175-0327.

MacNeil C, Dick JTA, Elwood RW. 1999. The dynamics of predation on Gammarus spp. (Crustacea: Amphipoda). Biological Reviews 74:375-395 DOI 10.1111/j.1469-185X.1999.tb00035.x.

MacNeil C, Dick JTA, Platvoet D, Briffa M. 2011. Direct and indirect effects of species displacements: an invading freshwater amphipod can disrupt leaf-litter processing and shredder efficiency. Journal of the North American Benthological Society 30:38-48 DOI 10.1899/10-056.1.

MacNeil C, Elwood RW, Dick JTA. 1999. Predator-prey interactions between brown trout Salmo trutta and native and introduced ampbipods; tbeir implications for fish diets. Ecography 22:686-696 DOI 10.1111/j.1600-0587.1999.tb00518.x.

MacNeil C, Platvoet D. 2005. The predatory impact of the freshwater invader Dikerogammarus villosus on native Gammarus pulex (Crustacea: Amphipoda); influences of differential microdistribution and food resources. Journal of Zoology 267:31-38 DOI $10.1017 /$ S0952836905007351. 
Martens A, Grabow K. 2008. Das Risiko der Verschleppung neozoischer Amphipoda beim Uberlandtransport von Yachten. Lauterbornia 62:41-44.

Martin CW. 2014. Naïve prey exhibit reduced antipredator behavior and survivorship. PeerJ 2:e665 DOI 10.7717/peerj.665.

Mastitsky SE, Makarevich OA. 2007. Distribution and abundance of Ponto-Caspian amphipods in the Belarusian section of the Dnieper River. Aquatic Invasions 2:39-44 DOI 10.3391/ai.2007.2.1.4.

Mayer G, Maas A, Waloszek D. 2012. Coexisting native and non-indigenous gammarideans in lake constance-comparative morphology of mouthparts (crustacea, amphipoda, gammaridea). Spixiana 35:269-285.

McCabe DJ, Beekey MA, Mazloff A, Marsden JE. 2006. Negative effect of zebra mussels on foraging and habitat use by lake sturgeon (Acipenser fulvescens). Aquatic Conservation: Marine and Freshwater Ecosystems 16:493-500 DOI 10.1002/aqc.754.

McCauley SJ, Rowe L, Fortin M-J. 2011. The deadly effects of "nonlethal” predators. Ecology 92:2043-2048 DOI 10.1890/11-0455.1.

Meijer K, Schilthuizen M, Beukeboom L, Smit C. 2016. A review and meta-analysis of the enemy release hypothesis in plant-herbivorous insect systems. PeerJ 4:e2778 DOI 10.7717/peerj.2778.

Mowles SL, Rundle SD, Cotton PA. 2011. Susceptibility to predation affects traitmediated indirect interactions by reversing interspecific competition. PLOS ONE 6:e23068 DOI 10.1371/journal.pone.0023068.

Muskó IB, Balogh C, Tóth ÁP, Varga É, Lakatos G. 2007. Differential response of invasive malacostracan species to lake level fluctuations. Hydrobiologia 590:65-74 DOI 10.1007/s10750-007-0758-7.

Pennuto C, Keppler D. 2008. Short-term predator avoidance behavior by invasive and native amphipods in the Great Lakes. Aquatic Ecology 42:629-641 DOI 10.1007/s10452-007-9139-6.

Perez KO, Carlson RL, Shulman MJ, Ellis JC. 2009. Why are intertidal snails rare in the subtidal? Predation, growth and the vertical distribution of Littorina littorea (L.) in the Gulf of Maine. Journal of Experimental Marine Biology and Ecology 369:79-86 DOI 10.1016/j.jembe.2008.09.019.

Perrot-Minnot MJ, Kaldonski N, Cézilly F. 2007. Increased susceptibility to predation and altered anti-predator behaviour in an acanthocephalan-infected amphipod. International Journal for Parasitology 37:645-651 DOI 10.1016/j.ijpara.2006.12.005.

Pettersson LB, Nilsson PA, Brönmark C. 2000. Predator recognition and defence strategies in crucian carp, Carassius carassius. Oikos 88:200-212

DOI 10.1034/j.1600-0706.2000.880122.x.

Pinchuk VI, Vasileva ED, Vasilev VP, Miller P. 2003. Neogobius gymnotrachelus (Kessler, 1857). In: Miller P, ed. The freshwater fishes of Europe, Vol. 8. I Mugilidae, Atherinidae, Atherinopsidae, Blenniidae, Odontobutidae, Gobiidae 1. Wiesbaden: AULA-Verlag, 264-279.

Platvoet D, Dick JTA, MacNeil C, Van Riel MC, Van der Velde G. 2009. Invader-invader interactions in relation to environmental heterogeneity leads to zonation of two 
invasive amphipods, Dikerogammarus villosus (Sowinsky) and Gammarus tigrinus Sexton: amphipod pilot species project (AMPIS) report 6. Biological Invasions 11:2085-2093 DOI 10.1007/s10530-009-9488-2.

Poznańska M, Kakareko T, Krzyzyński M, Kobak J. 2013. Effect of substratum drying on the survival and migrations of Ponto-Caspian and native gammarids (Crustacea: Amphipoda). Hydrobiologia 700:47-59 DOI 10.1007/s10750-012-1218-6.

Preisser EL, Bolnick DI, Benard MF. 2005. Scared to death? The effects of intimidation and consumption in predator-prey interactions. Ecology 86:501-509 DOI 10.1890/04-0719.

Rewicz T, Grabowski M, MacNeil C, Bącela-Spychalska K. 2014. The profile of a 'perfect' invader - the case of killer shrimp, Dikerogammarus villosus. Aquatic Invasions 9:267-288 DOI 10.3391/ai.2014.9.3.04.

Rewicz T, Wattier R, Rigaud T, Grabowski M, Mamos T, Bącela-Spychalska K. 2017. The killer shrimp, Dikerogammarus villosus, invading European Alpine Lakes: a single main source but independent founder events with an overall loss of genetic diversity. Freshwater Biology 62:1036-1051 DOI 10.1111/fwb.12923.

Rezsu E, Specziár A. 2006. Ontogenetic diet profiles and size-dependent diet partitioning of ruffe Gymnocephalus cernuus, perch Perca fluviatilis and pumpkinseed Lepomis gibbosus in Lake Balaton. Ecology of Freshwater Fish 15:339-349 DOI 10.1111/j.1600-0633.2006.00172.x.

Richter L, Schwenkmezger L, Becker J, Winkelmann C, Hellmann C, Worischka S. 2018. The very hungry amphipod: the invasive Dikerogammarus villosus shows high consumption rates for two food sources and independent of predator cues. Biological Invasions 20:1321-1335 DOI 10.1007/s10530-017-1629-4.

Salo P, Korpimaki E, Banks PB, Nordstrom M, Dickman CR. 2007. Alien predators are more dangerous than native predators to prey populations. Proceedings of the Royal Society B: Biological Sciences 274:1237-1243 DOI 10.1098/rspb.2006.0444.

Sheriff MJ, Thaler JS. 2014. Ecophysiological effects of predation risk; an integration across disciplines. Oecologia 176:607-611 DOI 10.1007/s00442-014-3105-5.

Šidagyte E, Solovjova S, Šniaukštaite V, Šiaulys A, Olenin S, Arbačiauskas K. 2017. The killer shrimp Dikerogammarus villosus (Crustacea, Amphipoda) invades Lithuanian waters, South-Eastern Baltic Sea. Oceanologia 59:85-91 DOI 10.1016/j.oceano.2016.08.004.

Sih A, Bolnick DI, Luttbeg B, Orrock JL, Peacor SD, Pintor LM, Preisser E, Rehage JS, Vonesh JR. 2010. Predator-prey naïveté, antipredator behavior, and the ecology of predator invasions. Oikos 119:610-621 DOI 10.1111/j.1600-0706.2009.18039.x.

Slos S, Stoks R. 2008. Predation risk induces stress proteins and reduces antioxidant defense. Functional Ecology 22:637-642 DOI 10.1111/j.1365-2435.2008.01424.x.

Ślusarczyk M, Dawidowicz P, Rygielska E. 2005. Hide, rest or die: a light-mediated diapause response in Daphnia magna to the threat of fish predation. Freshwater Biology 50:141-146 DOI 10.1111/j.1365-2427.2004.01309.x. 
Ślusarczyk M, Rygielska E. 2004. Fish faeces as the primary source of chemical cues inducing fish avoidance diapause in Daphnia magna. Hydrobiologia 526:231-234 DOI 10.1023/B:HYDR.0000041599.56610.b4.

Sornom P, Gismondi E, Vellinger C, Devin S, Férard J-F, Beisel J-N. 2012. Effects of sublethal cadmium exposure on antipredator behavioural and antitoxic responses in the invasive amphipod Dikerogammarus villosus. PLOS ONE 7:e42435 DOI 10.1371/journal.pone.0042435.

Szokoli F, Winkelmann C, Berendonk TU, Worischka S. 2015. The effects of fish kairomones and food availability on the predator avoidance behaviour of Gammarus pulex. Fundamental and Applied Limnology 186:249-258 DOI 10.1127/fal/2015/0633.

Thoms C, Schupp PJ, Custódio MR, Lôbo-Hajdu G, Hajdu E, Muricy G. 2007. Chemical defense strategies in sponges: a review. Porifera Research: Biodiversity, Innovation and Sustainability 28:627-637.

Torchin ME, Lafferty KD, Dobson AP, McKenzie VJ, Kuris AM. 2003. Introduced species and their missing parasites. Nature 421:628-630 DOI 10.1038/nature01346.

Turner AM, Peacor SD. 2012. Scaling up infochemicals. In: Chemical ecology in aquatic systems. Oxford: Oxford University Press, 140-157.

Ueshima E, Yusa Y. 2015. Antipredator behaviour in response to single or combined predator cues in the apple snail Pomacea canaliculata. Journal of Molluscan Studies 81:51-57 DOI 10.1093/mollus/eyu057.

Van Riel MC, Healy EP, Van der Velde G, Bij de Vaate A. 2007. Interference competition among native and invader amphipods. Acta Oecologica 31:282-289 DOI 10.1016/j.actao.2006.12.006.

Van Riel MC, Van der Velde G, Rajagopal S, Marguillier S, Dehairs F, Bij de Vaate A. 2006. Trophic relationships in the Rhine food web during invasion and after establishment of the Ponto-Caspian invader Dikerogammarus villosus. Hydrobiologia 565:39-58 DOI 10.1007/s10750-005-1904-8.

Von Elert E, Pohnert G. 2000. Predator specificity of kairomones in diel vertical migration of Daphnia: a chemical approach. Oikos 88:119-128

DOI 10.1034/j.1600-0706.2000.880114.x.

Weber A. 2003. More than one "fish kairomone"? Perch and stickleback kairomones affect Daphnia life history traits differently. Hydrobiologia 498:143-150 DOI 10.1023/A:1026297106626.

Werner EE, Peacor SD. 2003. A review of trait-mediated indirect interactions in ecological communities. Ecology 84:1083-1100 DOI 10.1890/0012-9658(2003)084[1083:AROTII]2.0.CO;2.

Wiạckowski K, Fyda J, Ciecko A. 2004. The behaviour of an omnivorous protozoan affects the extent of induced morphological defence in a protozoan prey. Freshwater Biology 49:801-809 DOI 10.1111/j.1365-2427.2004.01227.x.

Wisenden BD, Chivers DP, Smith RJF. 1997. Learned recognition of predation risk by Enallagma damselfly larvae (Odonata, Zygoptera) on the basis of chemical cues. Journal of Chemical Ecology 23:137-151 DOI 10.1023/B:JOEC.0000006350.66424.3d. 
Wisenden BD, Rugg ML, Korpi NL, Fuselier LC. 2009. Lab and field estimates of active time of chemical alarm cues of a cyprinid fish and an amphipod crustacean. Behaviour 146:1423-1442 DOI 10.1163/156853909X440998.

Wooster DE. 1998. Amphipod (Gammarus minus) responses to predators and predator impact on amphipod density. Oecologia 115:253-259 DOI 10.1007/s004420050514.

Wootton RJ. 1990. Ecology of teleost fishes. New York: Chapman and Hall.

Wudkevich K, Wisenden BD, Chivers DP, Smith RJF. 1997. Reactions of Gammarus lacustris to chemical stimuli from natural predators and injured conspecifics. Journal of Chemical Ecology 23:1163-1173 DOI 10.1023/B:JOEC.0000006393.92013.36.

Zuharah WF, Lester PJ. 2010. Are exotic invaders less susceptible to native predators? A test using native and exotic mosquito species in New Zealand. Population Ecology 53:307-317. 